\title{
Injeksi asam hialuronat di lapisan dermis menghambat peningkatan ekspresi MMP-1 tikus yang dipajan sinar ultraviolet-B (UVB)
}

\author{
${ }^{1}$ Oktavian Tamon, ${ }^{2}$ AAGP Wiraguna, ${ }^{3}$ Wimpie Pangkahila
}

\author{
${ }^{1}$ Program Pascasarjana Anti-Aging Medicine \\ ${ }^{2}$ Departemen Ilmu Kesehatan Kulit dan kelamin, \\ ${ }^{3}$ Departemen Andrologi dan Seksologi \\ Fakultas Kedokteran Universitas Udayana Denpasar \\ Email: oktavian.tamon@yahoo.co.id
}

\begin{abstract}
Ultraviolet B (UVB) is a source of free radicals that accelerate aging process, especially in the skin, through the increase of MMP-1. Hyaluronic acid contained in the dermal filler injection may provide a protective effect against skin exposure to UV rays. This study was aimed to prove that intradermal injection of hyaluronic acid could prevent the increase of MMP-1 in UVB-induced rats (Rattus norvegicus). This was a true experimental study with the post test only control group design. Subjects were 30 male Wistar rats (Rattus norvegicus), aged 2,5-3 months, weighing 160-180 g, and divided into 3 groups. The control group (P0) was exposed to UV-B only; the treatment group 1 (P1) was exposed to UVB and treated with placebo (aquadest intradermal injection); and the treatment group 2 (P2) was exposed to UVB and treated with hyaluronic acid intradermal injection. After 15 days of treatment, all rats were anesthetized and their skin tissues were prepared for examination of MMP1 levels. The statistic analysis showed that the average level of MMP1 in the P0 group was $24.54 \pm 4.39 \%$; in the P1 group was $21.35 \pm 2.48 \%(P<0.01)$. The average level of MMP1 in P2 group was $15.40 \pm 3.87 \%$, and was statistically lower than P0 group $(P<0.01)$ and P1 group $(P<0.01)$. Conclusion: Injection of hyaluronic acid in the dermal layer could prevent the increase of MMP-1 in UVB-induced rats (Rattus norvegicus).
\end{abstract}

Keywords: hyaluronic acid, MMP-1, UVB

\begin{abstract}
Abstrak: Ultraviolet B (UVB) merupakan salah satu sumber radikal bebas yang dapat mempercepat proses penuaan, khususnya penuaan pada kulit melalui peningkatan MMP-1. Asam hialuronat yang terkandung dalam dermal filler injection dapat memberi efek perlindungan kulit terhadap pajanan sinar ultraviolet. Tujuan penelitian ini untuk membuktikan bahwa pemberian asam hialuronat intradermal menghambat peningkatan ekspresi MMP-1 tikus yang dipapar sinar UVB. Jenis penelitian ialah eksperimental murni menggunakan post test only control group design. Subjek penelitian ialah 30 ekor tikus putih (Rattus norvegicus), jantan, galur Wistar, berumur 2,5-3 bulan, dengan berat badan 160-180 gram yang terbagi menjadi 3 kelompok masing-masing berjumlah 10 ekor tikus. Kelompok kontrol (P0) hanya diberi pajanan UVB; kelompok plasebo (P1) diberikan injeksi aquabidest intradermal serta pajanan UVB; dan kelompok perlakuan (P2) diberikan injeksi asam hialuronat intradermal dan pajanan UVB. Setelah 15 hari perlakuan, seluruh tikus dianestesi kemudian jaringan kulitnya diambil untuk pemeriksaan ekspresi MMP-1 dermis. Hasil analisis statistik menunjukkan bahwa rerata ekspresi MMP-1 pada kelompok P0 ialah $24,54 \pm 4,39 \%$ dan pada kelompok P1 21,35 $\pm 2,48 \%$ ( $P>0,05)$. Pada kelompok P2, rerata ekspresi MMP-1 ialah 15,40 $\pm 3,87 \%$, yang secara statistik lebih rendah dibandingkan dengan kelompok P0 $(P<0,01)$ dan kelompok P1 $(P<0,01)$. Simpulan: Pemberian asam hialuronat intradermal menghambat peningkatan ekspresi MMP-1 tikus yang dipapar sinar UVB.
\end{abstract}

Kata kunci: asam hialuronat, MMP-1, UVB 
Kulit merupakan salah satu organ yang paling nampak pada proses penuaan, terlebih lagi kulit ialah bagian yang paling rentan terpapar faktor-faktor eksternal seperti radiasi ultraviolet dan polutan lainnya. Radiasi sinar ultraviolet (UV) dari sinar matahari dengan panjang gelombang 100-400 nm merupakan 5\% dari seluruh radiasi sinar yang ada. Yang paling berpengaruh terhadap kerusakan kulit ialah ultraviolet-B (UVB), karena karakteristik panjang gelombang yang lebih pendek dan paling banyak menembus atmosfer bumi. ${ }^{1}$

Paparan radiasi ultraviolet tersebut menyebabkan penuaan kulit melalui beberapa jalur dan mekanisme, termasuk di dalamnya pembentukan sunburn cell, tercetusnya respon peradangan, terbentuknya thymine dimer dan produksi kolagenase (MMP/matrix metalloproteinase). ${ }^{1}$ MMP merupakan enzim proteinase mengandung zinc yang berperan penting pada proses degradasi protein matriks ekstrasel. Sinar ultraviolet ini juga sangat terbukti meningkatkan degradasi kolagen melalui aktivasi MMP. Selain itu, sinar ultraviolet dapat memicu sintesis MMP-1 dan MMP-3 melalui pelepasan tumor necrosis factoraphfa (TNF- $\alpha)^{2,3}$

Asam hialuronat dapat mencegah penuaan kulit akibat paparan UVB. Penelitian pada kultur fibroblas menunjukkan asam hialuronat meningkatkan proliferasi dan sintesis tissue factor inhibitor of metalloproteinase 1 (TIMP-1), menurunkan MMP-1, serta meningkatkan proliferasi dan sintesis kolagen tipe 1 (COL1A1) dan transforming growth factor- $\alpha$ (TGF- $\alpha)$. Pada penelitian tersebut, setelah 24 jam secara statistik terjadi peningkatan nyata dari ekspresi gen TIMP1 dan setelah 24 jam berikutnya secara statistik terjadi penurunan secara signifikan ekspresi gen MMP-1. ${ }^{4}$

Injeksi asam hialuronat intra-artikular dengan dosis 1 atau $3 \mathrm{mg} / \mathrm{ml}$ menunjukkan hasil yang bermakna terhadap penurunan ekspresi MMP-13. ${ }^{5}$ Di samping itu pemberian asam hialuronat menunjukkan supresi dari ekspresi MMP-1 pada dosis 1 $\mathrm{mg} / \mathrm{ml}^{6}{ }^{6}$ Dalam kaitan asam hialuronat dan degradasi kolagen, pada kulit manusia MMP-1 ialah tipe yang paling terpengaruh oleh induksi sinar UV matahari dan bertanggung jawab terhadap degradasi kolagen pada kulit yang mengalami photoaging. ${ }^{7}$

Dengan demikian hambatan terhadap MMP-1 merupakan salah satu cara untuk mencegah kerusakan kulit akibat paparan sinar UV. MMP-1 adalah mediator yang mendegradasi kolagen pada kulit yang mengalami photoaging. ${ }^{8}$ Penelitian sebelumnya mengenai pengukuran ekspresi TIMP-1 dan ekspresi MMP-1 secara in vitro, mendapatkan adanya peningkatan inhibitor MMP-1 dan supresi ekspresi MMP-1. Penelitian ini dilakukan secara in vivo dengan penyuntikan asam hialuronat intradermal pada tikus yang dipapar sinar UVB untuk melihat peningkatan ekspresi MMP-1 pada dermis

\section{METODE PENELITIAN}

Jenis penelitian ini ialah eksperimental murni dengan menggunakan completely randomized post test only control group design. Subyek penelitian ialah 30 ekor tikus (Rattus norvegicus), jantan, galur Wistar, dewasa, berumur 2,5-3 bulan, dengan berat badan 180-200 gr yang dibagi menjadi 3 (tiga) kelompok masing-masing berjumlah 10 ekor tikus. Kelompok pertama (P0) sebagai kelompok kontrol hanya diberi pajanan UVB. Kelompok kedua (P1) yaitu kelompok perlakuan 1 diberikan injeksi aquabidest secara intradermal dan pajanan UVB. Kelompok ketiga (P2) yaitu kelompok perlakuan 2 yang diberikan injeksi asam hialuronat secara intradermal dan pajanan UVB.

Sebelum perlakuan, seluruh tikus diadaptasi selama beberapa hari di dalam kandang dengan diberi makan dan minum ad libitum. Asam hialuronat (Juvederm ${ }^{\circledR}$ ) konsentrasi $20 \mathrm{mg} / \mathrm{ml}$ diberikan dengan cara suntikan di lapisan dermis (di bawah kulit) dengan dosis $20 \mathrm{mg} / \mathrm{ml}$ sebanyak 0,1 ml. Sinar UVB (TL UVB 20 watt; Phillips®) diberikan setiap 48 jam sekali dengan dosis total $80 \mathrm{~mJ} / \mathrm{cm}^{2}$. Perlakuan dilakukan selama 15 hari. Setelah 24 jam 
sejak penyinaran terakhir, tikus di eutanasia menggunakan xylazine dan ketamine dengan dosis masing-masing 4-8 $\mathrm{mg} / \mathrm{kgBB}$ IM dan 22-44 mg/kgBB IM. Sampel biopsi kulit dibekukan di suhu $-80^{\circ} \mathrm{C}$. Kemudian spesimen kulit tersebut dilakukan pemeriksaan imunnohistokimia jaringan untuk penghitungan ekspresi MMP-1.

Hasil penelitian dianalisis dan disajikan menggunakan analisis deskriptif, normalitas data, homogenitas data, dan uji komparabilitas.

\section{HASIL PENELITIAN DAN BAHASAN}

Hasil penelitian menunjukkan rerata jumlah MMP1 pada kelompok kontrol (P0) yang hanya diberi pajanan UVB ialah 24,54 $\pm 4,39 \%$; pada kelompok perlakuan 1 (P1) yang diberikan injeksi aquabidest secara intradermal serta diberikan pajanan UVB adalah $21,35 \pm 2,48 \%$, dan pada kelompok perlakuan 2 (P2) yang diberikan injeksi asam hialuronat secara intradermal serta diberikan pajanan UVB ialah $15,40 \pm 3,87 \%$ $(P<0,01)$. Uji lanjutan untuk mengetahui perbedaan individual antar kelompok dengan menggunakan Least Significance Difference (LSD) test (Tabel 1) menunjukkan bahwa terdapat perbedaan nyata antara kelompok P0 dengan kelompok P1 $(P>0,05)$, kelompok P1 dengan $\mathrm{P} 2(P<0,01)$ dan juga terdapat perbedaan bermakna antara kelompok $\mathrm{P} 0$ dengan $\mathrm{P} 2(P<0,01)$.

Tabel 1. Perbandingan rerata ekspresi MMP-1 antar kelompok

\begin{tabular}{lcccc}
\hline \multicolumn{1}{c}{ Kelompok } & n & Rerata (\%) & $\boldsymbol{F}$ & $\boldsymbol{P}$ \\
\hline Kontrol (P0) & 10 & $24,54 \pm 4,39^{\mathrm{a}}$ & & \\
Perlakuan 1 (P1) & 10 & $21,35 \pm 2,48^{\mathrm{a}}$ & 15,941 & 0,000 \\
Perlakuan 2 (P2) & 10 & $15,40 \pm 3,87^{\mathrm{b}}$ & & \\
\hline
\end{tabular}

*Notasi berbeda $(\mathrm{a}, \mathrm{b})$ menunjukkan berbeda bermakna $(P<0,05)$. Notasi yang sama menunjukkan tidak berbeda bermakna $(P>0,05)$; diuji menggunakan Least Significance Difference test

A

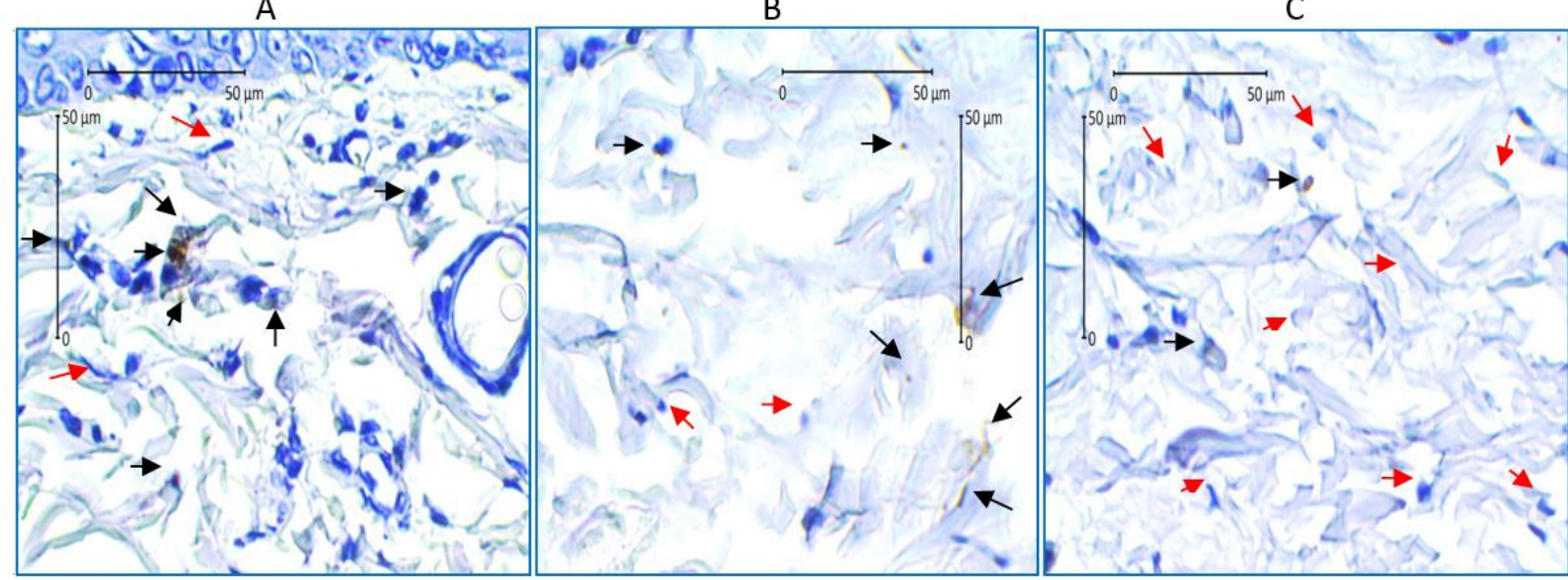

Gambar 1. Hasil pemeriksaan imunohistokimia jaringan dermis tikus. Sediaan dilihat dengan mikroskop Olympus CX41 (Japan) dan difoto dengan kamera Optilab-pro (Miconos, Indonesia) dengan perangkat lunak Optilab viewer 1.0 dan Image Raster 2.1

Asam hialuronat merupakan polimer dari asam N-asetilhialobiuronat dan merupakan polisakarida alami yang menyusun jaringan ikat. Kadar asam hialuronat yang tinggi diduga dapat mengurangi resistensi terhadap migrasi sel, berperan sebagai protektor terhadap kerusakan jaringan akibat stress oksidatif 
dan mengurangi terbentuknya skar pada proses penyembuhan luka. ${ }^{9}$

Penelitian in-vitro dengan penambahan asam hialuronat pada kultur fibroblas dapat meningkatkan proliferasi dan sintesis TIMP-1, menurunkan MMP-1, meningkatkan proliferasi dan sintesis dari COL1A1 dan TGF- $\beta$. Penambahan anti CD-44 pada kultur fibroblas sebaliknya akan menurunkan proliferasi sel dan sintesis kolagen. Hal ini mengindikasikan peranan reseptor sebagai perantara dalam proses tersebut. Pada penelitian tersebut, setelah 24 jam secara statistik terjadi peningkatan nyata dari ekspresi gen TIMP-1 dan setelah 24 jam berikutnya secara statistik terjadi penurunan secara bermakna ekspresi gen MMP-1. ${ }^{4}$

Banyak penelitian telah dilakukan di bidang reumatologi berkaitan dengan penggunaan asam hialuronat sebagai terapi pada osteoartritis. Penelitian terhadap 12 pasien osteoartritis yang diberikan injeksi asam hialuronat intra-artikular dengan dosis 1 atau $3 \mathrm{mg} / \mathrm{ml}$ menunjukkan hasil bermakna terhadap penurunan ekspresi MMP-13.s yang lebih besar pada osteoartritis grade-IV dibandingan pada osteoartritis grade-II. Di samping itu pemberian asam hialuronat menunjukkan supresi dari ekspresi MMP-1 pada dosis 1 $\mathrm{mg} / \mathrm{ml}$. $^{5,6}$

Asam hialuronat dan interaksinya dengan CD-44 memungkinkan untuk menstabilkan dan memantapkan sintesis kolagen dan fungsi normal kulit. Asam hialuronat secara normal terdapat pada matriks ekstrasel pada basal keratinosit dan menyusun kolagen dermis dengan jalan stimulasi fragmentasi kolagen dan penetrasi fibroblas. Penurunan kadar asam hialuronat berhubungan dengan penurunan elastisitas kulit, memungkinkan respon inflamasi, dan menurunkan perbaikan jaringan karena proses degenerasi dari matriks jaringan granular. ${ }^{10}$

Selain itu asam hialuronat dengan berat molekul tinggi juga memiliki efek proteksi terhadap bahaya ROS. ${ }^{11}$ Asam hialuronat dapat menghambat efek ROS terhadap peningkatan aktivator protein 1 sehingga menurukan ekspresi MMP-1. Pemberian senyawa dengan aktivitas antioksidan diharapkan dapat mencegah terjadinya kerusakan oksidatif pada kulit sehingga mencegah peningkatan kadar MMP-1.

Pada penelitian ini, antara kelompok kontrol P0 (yang hanya diberikan paparan UVB) dan kelompok plasebo P1 (yang diberikan aquadest dan paparan UVB) ternyata dari hasil analisis deskriptif terdapat penurunan nilai yaitu kelompok $\mathrm{P} 0$ $24,54 \%$ dan P1 21,35\%. Hal ini menunjukkan adanya penghambatan ekspresi walaupun pada analisis LSD tidak bermakna. Hal tersebut mungkin bisa disebabkan oleh pengaruh atom hidrogen pada molekul air $\left(\mathrm{H}_{2} \mathrm{O}\right)$ yang bisa mencegah kerusakan DNA dan juga menghambat ekspresi MMP-1, COX-2, IL6, dan IL-1 $\beta$.

Pada penelitian $\mathrm{Mi}$ et al. ${ }^{12}$ dibuktikan bahwa pemberian atom hidrogen dalam hal ini pemberian aquadest bisa memodulasi respon kulit baik lapisan epidermis maupun lapisan dermis terhadap paparan UV dan meregulasi basal gene expression pada kulit. Mekanisme kerjanya dapat dijelaskan bahwa atom hdrogen bekerja pada jalur mitogen-activated protein kinase (MAPK) dengan cara penghambatan fosforilasi cjun, tetapi c-fos tidak dihambat.

Penghambatan ekspresi MMP-1 kemungkinan dimediasi oleh penurunan level fosforilasi dari SEK1/JNK dan c-jun, yang diketahui berkaitan erat dengan aktivasi AP-1 dan tidak dilaporkan adanya pengaruh pada jalur aktivasi NF-kB. ${ }^{12}$ Penelitian lain pada sel mamalia menunjukkan dengan penambahan atom hidrogen pada aquadest menunjukkan efek proteksi yang bermakna terhadap radikal hidroksil $(\mathrm{OH} \bullet)^{13}$

\section{SIMPULAN}

Berdasarkan hasil penelitian dapat disimpulkan bahwa pemberian asam hialuronat pada lapisan dermis menghambat peningkatan ekspresi enzim matrix metalloproteinase type 1 (MMP-1) pada tikus yang dipajan dengan sinar UVB.

Perlu dilakukan uji toksisitas asam 
hialuronat untuk mengetahui dosis injeksi dan potensi efek samping injeksi jangka panjang pada dosis tertentu. Selain itu, diperlukan uji klinik pada manusia yang memiliki tingkat sensitivitas terhadap bahan kimia yang berbeda.

\section{DAFTAR PUSTAKA}

1. Baumann L. Commentary: How to prevent photoaging? J Invest Dermatol. 2005;125:xii-xiii. Doi:10.111/j.0022202x.2005.23810x

2. Gilchrest BA, Krutmann J. Skin Aging. Berlin: Springer-Verlag, 2006; p. 4, 33-43.

3. Quan T, Qin Z, Xia W, Shao Y, Voorhees JJ, Fisher GJ. Matrix degrading metalloproteinases in photoaging. J Investig Dermatol. Symp Proc. 2009;14(1):20-4.

4. Monteiro RM. 2013. Culture of human dermal fibroblast in the presence of hyaluronic acid and polyethylene glycol: effects on cell proliferation, collagen production, and related enzymes linked to the remodeling of the extracellular matrix. Surg Cosmet Dermatol. 2013;5(3):222-5.

5. Altman R, Manjoo A, Fierlinger A, Niazi F, Nicholls $M$. The mechanism of action for hyaluronic acid treatment in the osteoarthritic knee: a systematic review. BMC Musculoskeletal Disorders. 2015;16:321.

6. Pohlig F. Hyaluronic acid suppress the expression of metalloproteinases in osteoarthritis cartilage stimulated simultaneous by interleukin $1 \beta$ and mechanical load. PLoSONE. 2016; 11(3):e0150020.
7. Fisher GJ, Choi HC, Csorgo ZB, Shao Y, Datta S, Wang ZQ, et al. Ultraviolet irradiation increases matrix metalloproteinase- 8 protein in human skin in vivo. J Invest Dermatol. 2001; 117:219-26.

8. Fisher GJ, Quan T, Purohit T, Shao Y, Cho MK, Varani J, et al. 2009. Collagen fragmentation promotes oxidative stress and elevates matrix metalloproteinase-1 in fibroblast in aged human skin. Am J Pathol. 2009;174:101-15.

9. Falanga V. Mechanisms of cutaneous wound repair. In: Freedberg IM, Wolff K, Eisen AZ, editors. Fizpatrick's Dermatology in General Medicine (6th ed). New York: McGraw-Hill 2003; p. 236-46.

10. Fisher GJ. Fibroblast collapse and therapeutic implications. Arch Dermatol. 2008;144(5):666-72.

11. Malgorzata L, Alicja K, Tomasz G. Hyaluronic acid in inflamation and tissue regeneration. Wounds. 2016; 28:78-88.

12. Mi HS, Park RE, Nojima H, Kim HC, Yeon KK, Jin HC. Atomic hydrogen surrounded by water molecules, $\mathrm{H}(\mathrm{H} 2 \mathrm{O})_{\mathrm{m}}$, modulates basal and UVinduced gene expressions in human skin in vivo. PLoS One. 2013;8(4):e61696.

13. Nojima H, Park RE, Kwon JH, Suh I, Jeon J. 2007. Novel atmospheric pressure plasma device releasing atomic hydrogen; reduction of microbial-contamitants and $\mathrm{OH}$ radicals in the air. J Phys D: Appl Phys. 2007;40:501. 